KOMUNIKASI RINGKAS

\title{
STUDI PENDAHULUAN PENGARUH PADAT TEBAR INDUK SOTONG BULUH, Sepioteuthis lessoniana TERHADAP PERTUMBUHAN DAN SINTASAN DALAM KERAMBA JARING APUNG
}

\author{
Daud S. Pongsapan*), Usman*) dan Taufik Ahmad*)
}

\begin{abstract}
ABSTRAK
Penelitian dilakukan selama satu bulan di Teluk Labuange Kabupaten Barru, Sulawesi Selatan, menggunakan keramba ukuran $2 \times 2 \times 2 \mathrm{~m}^{3}$ yang terbuat dari jaring polietilen ukuran mata $3 / 4$ inci. Penelitian ini bertujuan untuk mengetahui pengaruh kepadatan terhadap pertumbuhan dan tingkat sintasan induk sotongbuluh dalam keramba jaring apung di laut. Perlakuan kepadatan induk sotong buluh yang dicobakan adalah 10, 20 dan 30 ekor/keramba. Semua induk uji diberi pakan rucah secara satiasi. Masing-masing perlakuan terdiri atas dua ulangan dan dirancang dalam rancangan acak lengkap (RAL).

Hasil analisis statistik menunjukkan bahwa perlakuan yang dicobakan tidak memperlihatkan perbedaan yang nyata $(P>0,05)$ baik terhadap pertumbuhan, maupun sintasan. Persentase jumlah polong yang mengandung $1,2,3,4,5,6$, dan 7 inti berturut-turut 1,$60 ; 8,20 ; 30,95 ; 39,60$; 16,$20 ; 3.40$; dan $0.05 \%$, dan tidak dipengaruhi oleh perlakuan.

ABSTRACT: Preliminary study on the effect on growth and survival rate of stocking density of big fin squid, Sepioteuthis lessoniana raised in floating net cages. By: Daud S. Pongsapan, Usman and Taufik Ahmad.

The study was conducted in Labuange Bay, South Sulawesi for 30 days using cages of $2 \times 2 \times 2$ $m^{3}$, which were made of $3 / 4$ inch mesh size polyethlene net. The objective of the experiment was to find out the effect of stocking density on growth and survival rate of bigfin squid cultured in floating net cages. The tested stocking densities were 10,20, and 30 ind./cage. Each treatment was duplicated. The bigfin squid were fed trash fish at satiation. Completely randomized designed was applied. There were no significant differences $(P>0.05)$ on survival rate and growth among treatments. The percentages of capsule containing $1,2,3,4,5,6$, and 7 nucleus were 1.60; 8.20;30.95; $39.60 ; 16.20 ; 3,40$; and $0.05 \%$ respectively and they were not affected by treatments.
\end{abstract}

KEYWORDS : stocking density, growth, survival, bigfin squid.

\section{PENDAHULUAN}

Sotong buluh, Sepioteuthis lessoniana merupakan salah satu jenis hewan neritik, hidup bergerombol dan terkonsentrasi pada perairan pantai yang mempunyai ekosistem lamun dan karang, dengan daerah sebaran mulai dari permukaan hingga kedalaman $100 \mathrm{~m}$. Jenis cumi-cumi ini mempunyai ukuran yang cukup besar yaitu dapat mencapai panjang mantel $36 \mathrm{~cm}$ dengan bobot sekitar 1,8 kg/ekor (Hamzah \& Manik, 1991; Roper et al., 1984). Sudjoko (1988) mengatakan bahwa nilai ekonomi kelompok sotong, cumi-cumi dan gurita yang termasuk dalam kelas Cepha- lophoda menduduki urutan ke tiga dalam dunia perikanan setelah ikan dan udang.

Hingga saat ini produksi cumi-cumi sepenuh. nya masih mengandalkan hasil penangkapan di alam. Akibat dari penangkapan yang terus menerus dikhawatirkan suatu saat akan terjadi tekanan terhadap kelestarian sumber daya tersebut. Upaya perbenihan untuk menunjang budidaya dan restocking merupakan salah satu alternatif yang dapat menjamin kesinambungan produksi sekaligus dapat mengurangi tekanan terhadap kelestarian sumber daya tersebut. Usaha pembenihan sotong buluh skala laborato-

Peneliti pada Balai Penelitian Perikanan Pantai 
rium telah berhasil dilakukan oleh Balai Penelitian Perikanan Pantai, namun masih mengalami beberapa kendala yang perlu segera diatasi. Satu di antara kendala tersebut adalah tingginya mortalitas induk selama pemeliharaan dalam keramba jaring apung terutama induk betina (Danakusumah, 1993). Padat penebaran diduga merupakan salah satu faktor yang dapat menyebabkan tingginya mortalitas pada induk sotong buluh karena padat penebaran berpengaruh terhadap efisiensi pemanfaatan ruang, pakan serta daya dukung wadah.

Informasi mengenai padat penebaran induk sotong buluh yang optimal sesuai dengan daya dukung wadah masih sangat terbatas. Bertitik tolak dari permasalahan tersebut maka dilakukan penelitian untuk mengetahui padat penebaran optimal induk sotong buluh dalam keramba jaring apung terhadap sintasan dan pertumbuhannya. Informasi yang diperoleh diharapkan dapat menjadi acuan dalam pengelolaan budidaya sotong buluh di kemudian hari.

\section{BAHAN DAN METODE}

Penelitian dilakukan selama 30 hari di Teluk Labuange, Kabupaten Barru Propinsi Sulawesi Selatan, menggunakan wadah berupa keramba jaring apung ukuran $2 \times 2 \times 2 \mathrm{~m}^{3}$. Keramba terbuat dari jaring polietilen berukuran mata $3 / 4$ inci, yang dipasang pada sebuah rakit ukuran $6 \times 9 \mathrm{~m}^{2}$, di mana $25 \mathrm{~cm}$ dari permukaan keramba mencuat ke permukaan, sehingga volume per keramba 7 $\mathrm{m}^{3}$. Sebagai hewan uji digunakan induk sotong buluh ukuran awal 144-157 g/ekor yang diperoleh dari hasil pancing nelayan dengan menggunakan jigs (pancing dengan umpan palsu yang menyerupai udang) di sekitar lokasi penelitian. Sebelum ditebar ke keramba percobaan, hewan uji terlebih dahulu diadaptasikan selama 4-6 hari dan diberi pakan rucah dari ikan tembang (Sardinella sp.), ikan pisang-pisang (Dipterygonotus balteatus), ikan selar (Selar boops dan Selar crumenophthalmus). Pakan diberikan sebanyak tiga kali sehari (pagi, siang dan malam) secara satiasi. Selain itu pada setiap keramba dipasang lampu dinyalakan pada malam hari untuk menarik pakan alami dari luar ke dalam keramba sebagai pakan tambahan.

Padat penebaran induk sotong buluh yang diaplikasikan adalah 10,20, dan 30 ekor/keramba, dan dirancang dalam rancangan acak lengkap
(RAL), masing-masing perlakuan terdiri atas dua ulangan. Penelitian ini hanya diulang dua kali mengingat induk sotong buluh apabila sudah ditampung dalam keramba penampungan selama lebih dari empat hari, maka induk-induk tersebut sudah mulai melepaskan telur dan akan terus bertelur sampai induk tersebut mati. Oleh karena itu untuk memperoleh induk yang seragam dalam waktu yang relatif singkat dan dalam jumlah banyak sangat sulit.

Penimbangan hewan uji dilakukan hanya pada awal dan akhir penelitian dengan meng. gunakan timbangan OHAUS dengan ketelitian $0,1 \mathrm{~g}$. Data yang diamati meliputi laju pertumbuhan harian dengan menggunakan rumus NRC (1977), sintasan dengan menggunakan rumus Effendie (1979). Selain itu juga dilakukan peng. amatan terhadap telur yang dihasilkan meliputi jumlah polong serta jumlah inti yang terdapat dalam polong tersebut. Perhitungan jumlah polong telur serta jumlah inti telur yang terdapat di dalam setiap polong dilakukan dengan menghitung satu per satu semua telur yang dihasilkan oleh induk cumi-cumi selama pemeliharaan. Selain itu juga dilakukan pengamatan terhadap beberapa peubah kualitas air meliputi salinitas dengan menggunakan refractometer, kecerahan dengan pinggan secchi, $\mathrm{pH}$ dengan menggunakan $p H$ solution, kecepatan arus dengan current meter, suhu dan oksigen terlarut dengan DO meter YSI model.

Untuk mengetahui pengaruh perlakuan yang dicobakan terhadap pertumbuhan dan sintasan sotong buluh maka dilakukan analisis ragam dengan bantuan paket program statistik, sedang kelayakan kualitas air untuk mendukung kehidupan hewan uji dianalisis secara deskriptif.

\section{HASIL DAN PEMBAHASAN}

\section{Tingkat Sintasan}

Persentase tingkat sintasan yang diperoleh pada padat penebaran 10,20 dan 30 ekor $/ 7 \mathrm{~m}^{3}$ berturut-turut 50, 40 dan 30\% (Tabel 1). Hasil analisis ragam memperlihatkan perbedaan yang tidak nyata $(\mathrm{P}>0,05)$ antara ke tiga perlakuan terhadap sintasan. Hasil pengamatan selama percobaan tampak bahwa umumnya induk sotong buluh betina yang telah beberapa kali melepas. kan telur akan mati, namun berapa kali bertelur setiap ekornya sebelum mati tidak dapat dike- 
tahui dengan pasti, karena umumnya cumi-cumi melepaskan telurnya pada malam hari. Sedang cumi-cumi yang berkelamin jantan umumnya dapat bertahan hidup sampai akhir penelitian.

Tingginya tingkat mortalitas pada induk sotong buluh betina yang telah melepaskan telur diduga disebabkan karena sebagian besar energi yang diperoleh dari pakan dialokasikan untuk perkembangan gonad dan proses pengeluaran telur sehingga enersi yang dapat dialokasikan untuk pertumbuhan bobot, pergerakan dan untuk proses metabolisme serta aktivitas lainnya sangat kecil. Selain itu diduga juga disebabkan karena kandungan nilai nutrisi yang terkandung dalam pakan rucah tidak mencukupi kabutuhan nutrisi pakan induk cumi-cumi khususnya betina, akibatnya akan terjadi defisit enersi yang pada akhirnya menyebabkan kematian induk betina tersebut. Ray (1979) mengatakan bahwa energi yang diperoleh dari pakan dapat dimanfaatkan untuk keperluan proses metabolisme, pertumbuh. an bobot, perkembangan gonad dan sebagian hilang melalui urine dan faeses.

\section{Pertumbuhan}

Pertumbuhan mutlak induk sotong buluh selama 30 hari pemeliharaan hampir merata pada ketiga perlakuan yang diaplikasikan. Pertumbuhan mutlak yang diperoleh pada perlakuan 10, 20 dan 30 ekor $/ 7 \mathrm{~m}^{3}$ berturut turut adalah 116,2 g; 94,9 dan 72,2 g/ekor. Laju pertumbuhan harian yang diperoleh pada padat penebaran 10 ,
20, dan 30 ekor/7 $\mathrm{m}^{3}$ berturut-turut 1,$78 ; 1,70$; dan $1,38 \%$.

Hasil analisis sidik ragam menunjukkan bahwa perlakuan kepadatan yang diaplikasikan tidak memperlihatkan perbedaan yang nyata $(\mathrm{P}>0,05)$ terhadap laju pertumbuhan harian (Tabel 1). Pertumbuhan yang diperoleh pada percobaan ini lebih rendah dibandingkan dengan hasil penelitian Yamaguchi (1991) pada cumicumi jenis Sepia latimanus dan Sepia lycidas yang dipelihara dalam bak volume $0,45 \mathrm{~m}^{3}$. Cumi-cumi jenis $S$. latimanus dapat mencapai ukuran bobot $84,6 \mathrm{~g} /$ ekor setelah 98 hari masa pemeliharaan, sedang cumi-cumi jenis $S$. lycidas dapat mencapai ukuran 280 g/ekor setelah 240 hari masa pemeliharaan sejak menetas. Selanjutnya dikatakan bahwa cumi-cumi jenis S. lycidas mempunyai pertumbuhan tercepat ke dua setelah $S$. latimanus. Pada percobaan ini peningkatan padat penebaran yang diaplikasikan masih memperlihatkan adanya indikasi peningkatan bobot biomassa. Dengan kata lain kepadatan yang optimal belum terlampaui. Huet (1971) mengatakan bahwa daya dukung maksimal atau produksi sesaat maksimal telah tercapai apabila padat penebaran yang dicobakan telah menghasilkan penurunan pertumbuhan bobot bjomassa.

Selama percobaan terpantau bahwa pakan yang diberikan dan tenggelam sampai ke dasar keramba $80 \%$ tidak termakan lagi. Untuk menghindari pakan yang terbuang tersebut maka waktu pemberian, jenis dan dosis pemberian pakan perlu mendapat perhatian yang serius. Hasil pengamatan pemberian pakan selama per-

Tabel 1. Pertumbuhan harian, pertumbuhan bobot dan sintasan cumi-cumi dengan padat tebar berbeda selama 30 hari pemeliharaan.

Table 1. Daily growth rate, weight gain and survival rate of bigfin squid, Sepioteuthis lessoniana reared at different stocking densities for 30 days.

\begin{tabular}{lccc}
\hline \multirow{2}{*}{ Variabel (Variable) } & \multicolumn{3}{c}{ Padat tebar (Stocking density) (ind./cage) } \\
\cline { 2 - 4 } & $\mathbf{1 0}$ & $\mathbf{2 0}$ & $\mathbf{3 0}$ \\
\hline Bobot awal (Initial weight) (g/ind.) & $142.4 \pm 46.9$ & $144.4 \pm 66.4$ & $156.8 \pm 59.8$ \\
Bobot akhir (Final weight) (g/ind.) & $214.6 \pm 66.4$ & $239.3 \pm 76.0$ & $272.8 \pm 93.4$ \\
Total pertumbuhan bobot (Total weight gain) & 116.2 & 94.9 & 72.20 \\
(g/ind.) & $1.78^{\mathrm{a}}$ & $1.70^{\mathrm{a}}$ & $1.38^{\mathrm{a}}$ \\
Pertumbuhan harian (Daily growth rate) (\%/day) & $50.0^{\mathrm{a}}$ & $40.0^{\mathrm{a}}$ & $30.0^{\mathrm{a}}$ \\
\hline Sintasan (Survival rate) (\%) &
\end{tabular}

) Nilai pada baris yang diikuti huruf yang sama menunjukkan tidak berbeda nyata $(P>0,05)$

The values in the same row followed by similar letter are not significantly different $(P>0.05)$. 
cobaan nampak bahwa umumnya sotong buluh lebih menyukai pakan yang masih hidup dan segar. Hal ini sesuai dengan pendapat Camou \& Rodoni (1983) yang mengatakan bahwa cumicumi lebih menyukai pakan yang hidup dan masih aktif terutama dari kelompok krustase, ikan dan moluska. Selanjutnya Yamaguchi (1991) mengatakan bahwa problem utama pada budi. daya cumi-cumi adalah di samping cumi-cumi lebih menyukai pakan yang hidup dan aktif, juga cara pengumpulan telur yang sangat sulit karena umumnya cumi-cumi meletakkan telurnya pada daerah-daerah berkarang. Namun dalam penelitian ini penggunaan pakan yang masih hidup masih sulit diterapkan karena sulit memperoleh pakan hidup dalam jumlah yang banyak, sehingga pakan rucah merupakan alternatif yang tepat sebagai pakan pengganti, dengan catatan cara pemberian pakannya perlu diperhatikan sehingga pakan tidak ada yang tenggelam sampai ke dasar keramba.

Secara umum dapat dikatakan bahwa semakin tinggi padat tebar yang diaplikasikan maka pertumbuhan bobot akan semakin menurun, karena akan terjadi persaingan baik ruang gerak, oksigen terlarut maupun pakan. Hal seperti itu juga dijumpai pada percobaan ini, di mana laju pertumbuhan harian yang tertinggi diperoleh pada perlakuan 10 ekor $/ 7 \mathrm{~m}^{3}$ yaitu $1,78 \%$ /hari, kemudian diikuti oleh perlakuan 20 dan 30 ekor/ $7 \mathrm{~m}^{3}$ masing-masing 1,70 dan $1,38 \%$ /hari. Dengan melihat laju pertumbuhan bobot harian baik cumi-cumi muda maupun induk, kemudahan dalam memanfaatkan pakan berupa ikan rucah, mudah bertelur dengan tingkat penetasan yang tinggi antara 78,7-93,7\% (Gunarto, 1995), maka secara keseluruhan dapat dikatakan bahwa sotong buluh merupakan salah satu komoditas perikanan pantai yang berpeluang untuk dikem. bangkan menjadi spesies budidaya.

\section{Produksi Telur}

Jumlah polong dan inti yang terdapat di dalam setiap polong telur yang dihasilkan oleh induk sotong buluh sangat bervariasi sesuai dengan ukuran bobot. Semakin besar dan berat induk sotong buluh, maka jumlah polong telur yang dihasilkan serta jumlah inti yang terdapat dalam setiap polongnya akan semakin banyak. Jumlah polong yang dihasilkan per satu kali peneluran berkisar antara 78-408, dengan jumlah inti yang terkandung di dalamnya sebanyak 194-1.350. Jumlah polong telur yang dihasilkan ada yang mengandung $1,2,3,4,5,6$ dan 7 inti bakal larva (Gambar 1). Hasil perhitungan dari seluruh polong telur yang dihasilkan-selama penelitian, nampak bahwa persentase jumlah polong yang mengandung $1,2,3,4,5,6$ dan 7 inti berturut-turut adalah 1,$6 ; 8,2 ; 30,95 ; 39,6 ; 16,2$; 3,4 dan $0,05 \%$ (Gambar 2). Perhitungan jumlah polong dan jumlah inti telur yang terdapat dalam setiap polong dilakukan setelah induk cumi-cumi selesai melepaskan telur, dengan cara melepaskan telur dari jaring kemudian menghitung satu per satu. Perhitungan jumlah inti telur yang terdapat dalam setiap polong dapat dilakukan dengan mudah karena telur cumi-cumi transparan, sehingga inti telur calon embrio dengan jelas dapat dilihat dan dihitung. Dari data tersebut tampak bahwa persentase jumlah polong telur yang mengandung 3,4 , dan 5 inti lebih dominan berturut-turut 30,$95 ; 39,6$ dan $16,2 \%$, dibandingkan dengan polong yang mengandung $1,2,6$ dan 7 inti telur.

\section{Kualitas Air}

Kualitas perairan sebagai media hidup cumi-cumi sifatnya bervariasi pada setiap lokasi dan merupakan salah satu faktor pendukung penting dalam menunjang pertumbuhan dan sintasan hewan uji. Peubah kualitas perairan yang dipantau selama penelitian berlangsung disajikan pada Tabel 2.

Salinitas yang diamati selama percobaan berlangsung berada pada kisaran 29,0-35 ppt. Fluktuasi salinitas yang terjadi selama percobaan tergolong tinggi, terutama pada musim hujan sehingga salinitas turun drastis menjadi $29 \mathrm{ppt}$. Kondisi seperti ini diduga sebagai salah satu penyebab tingginya mortalitas. Yamaguchi (1991) melaporkan bahwa juwana cumi-cumi jenis Sepia latimanus yang dibudidayakan akan mati apabila kondisi salinitas di bawah 30 ppt. Oksigen terlarut pada pagi dan sore selama percobaan berada pada kisaran 6,5-10,1 ppm. Kisaran tersebut masih berada pada rentang yang layak bagi pertumbuhan sotong buluh, mengingat hewan laut umumnya dapat tumbuh normal pada kisaran oksigen terlarut 4-8 ppm (Ahmad et al., 1991).

Suhu selama percobaan berlangsung berada pada kisaran $24,1-31,8^{\circ} \mathrm{C}$. Suhu terendah diper- 
oleh pada musim hujan terutama pada kedalaman $1 \mathrm{~m}$ dari permukaan, dan tertinggi diperoleh pada musim kemarau. Suhu rata-rata yang diperoleh selama percobaan adalah $28,6 \pm 2,1^{\circ} \mathrm{C}$ (Tabel 2) dan masih layak untuk mendukung pertumbuhan dan kehidupan sotong buluh, mengingat sotong buluh mampu hidup mulai dari permukaan hingga kedalaman $100 \mathrm{~m}$. Nilai $\mathrm{pH}$ air selama percobaan berada pada kisaran 8,0-
9,0. Fluktuasi $\mathrm{pH}$ yang terjadi setiap hari sangat kecil, sehingga pengaruhnya terhadap pertumbuhan dan kehidupan sotong buluh dapat diabaikan. Kecepatan arus selama percobaan berada pada kisaran $5-25 \mathrm{~cm} / \mathrm{dt}$ (Tabel 2). Kecepatan arus terendah terukur pada saat pasang harian sudah mencapai titik puncak dan pada masa peralihan musim dari musim timur ke musim barat.

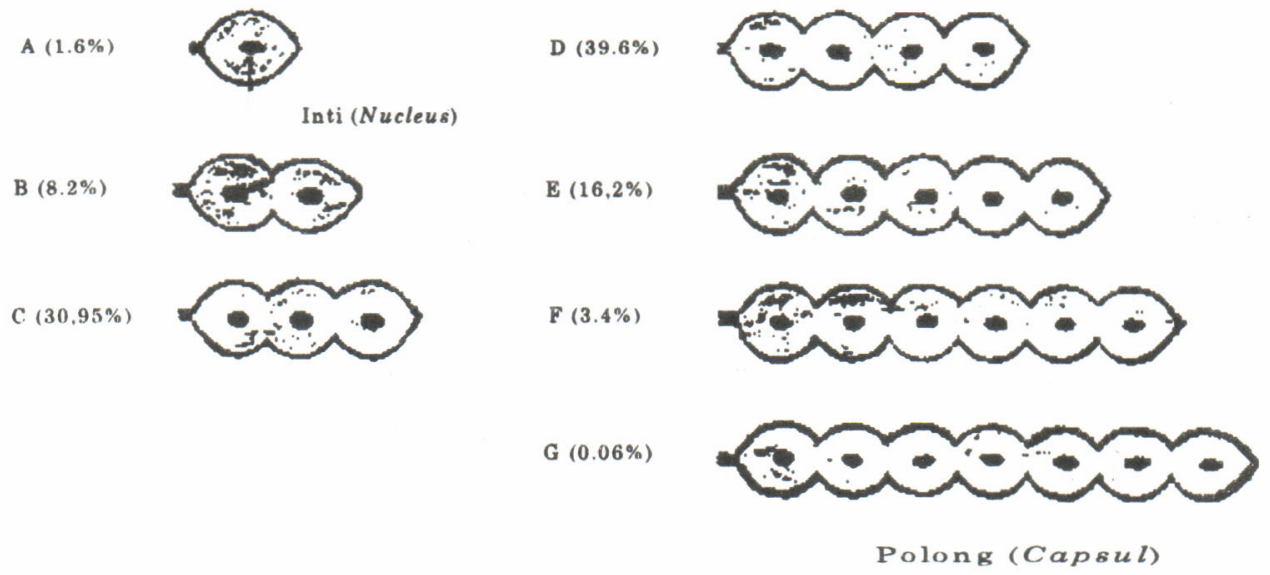

Gambar 1. Telur sotong buluh berisi jumlah inti yang berbeda (A, B, C, D, E, F, G berisi masing-masing satu, dua, tiga, empat, lima, enam dan tujuh inti).

Figure 1. Eggs of bigfin squid, Sepioteuthis lessoniana, containing different numbers of nucleus (A, $B, C, D, E, F, G$ containing one, two, three, four, five, six and seven nucleus).

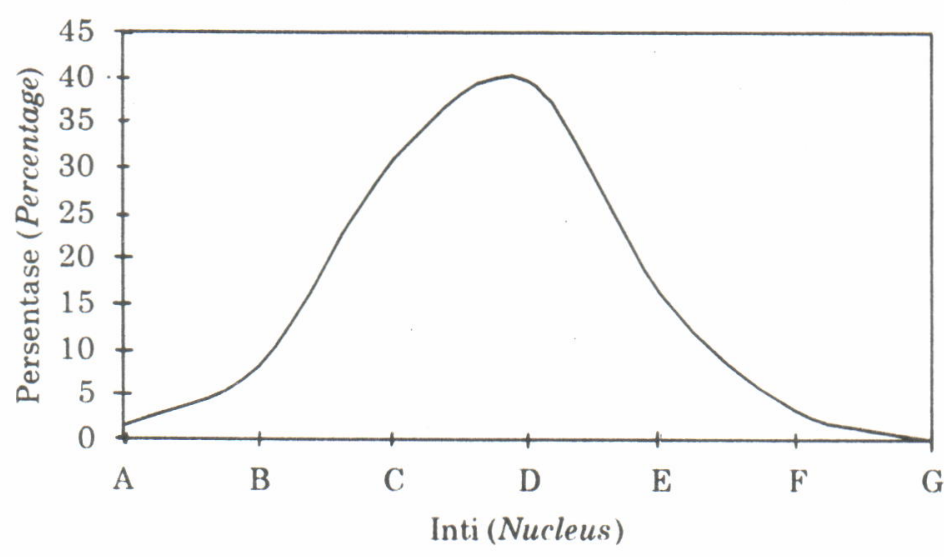

Gambar 2. Distribusi jumlah telur/inti masing-masing polong A (1,6\%), B (8,2\%), C (30,95\%), D (39,6\%), $\mathrm{E}(16,2 \%), \mathrm{F}(3,4 \%)$ and $\mathrm{G}(0,05 \%)$.

Figure 2. Distribution of egg/nucleus number in each capsul collected during the experiment A $(1.6 \%)$, $B(8.2 \%), C(30.95 \%), D(39,6 \%), E(16.2 \%), F(3.4 \%)$ and $G(0.05 \%)$. 
Tabel 2. Kisaran dan rata-rata peubah kualitas air yang diamati selama penelitian.

Table 2. Range and average of water quality parameters were monitored during the experiment.

\begin{tabular}{lrrr}
\hline \multicolumn{1}{c}{$\begin{array}{c}\text { Peubah } \\
\text { Variables }\end{array}$} & & $\begin{array}{c}\text { Kisaran } \\
\text { Range }\end{array}$ & $\begin{array}{c}\text { Rata-rata } \\
\text { Average }\end{array}$ \\
\hline Salinitas (Salinity) & $(\mathrm{ppt})$ & $29.0-35.0$ & $33.4 \pm 2.3$ \\
Oksigen terlarut (Dissolved Oxygen) & $(\mathrm{mg} / \mathrm{L})$ & $6.5-10.0$ & $8.4 \pm 0.2$ \\
$\mathrm{pH}$ & & $8.0-9.0$ & $8.5 \pm 0.2$ \\
Suhu (Temperature) & $\left({ }^{\circ} \mathrm{C}\right)$ & $24.1-31.9$ & $28.6 \pm 2.1$ \\
Velositas (Curret velocity) & $(\mathrm{Cm} / \mathrm{s})$ & $5.0-25.0$ & $15.4 \pm 6.6$ \\
Kecerahan (Transparancy) & $(\mathrm{m})$ & $4.0-6.5$ & $5.0 \pm 2.1$ \\
\hline
\end{tabular}

\section{KESIMPULAN}

Perlakuan padat penebaran yang diaplikasikan belum memperlihatkan perbedaan yang nyata, sehingga perlu penelitian lanjutan peningkatan padat tebar yang lebih tinggi.

\section{UCAPAN TERIMAKASIH}

Ucapan terima kasih disampaikan dengan hormat kepada teknisi Litkayasa Balitkanta atas nama A.M. Sabir dan Umar yang telah banyak membantu selama penelitian ini berlangsung.

\section{DAFTAR PUSTAKA}

Ahmad, T., P.T. Imanto, Muchari, A. Basyarie, P. Sunyoto, B. Slamet, Mayunar, R. Purba, S. Diani, S. Redjeki, S.A.Prabowo, dan S. Murtiningsih. 1991. Operasional pembesaran ikan kerapu dalam keramba jaring apung. Balai Penelitian Perikanan Budidaya Pantai Maros. 59 hal.

Camou, E.B. and R. B. Rodoni. 1983. Feeding and digestion of Cephalophods. p. 149-180. In Salehuddin A.S.M. and Wilbur K.M. The Mollusca 5(2). Academic Press, New York-London. 386p.

Danakusumah, E. 1993. Studi pendahuluan tentang biologi dan budidaya cumi-cumi batu, Sepia sp. Warta Balai Penelitian Budidaya Pantai, Maros 5(1):31-32.

Effendie, M.I. 1979. Metode biologi perikanan hal 106-107. Cetakan I. Yayasan Dewi Sri, Bogor. 112 hal.
Gunarto, 1995. Penelitian penetasan telur sotong buluh, Sepioteuthis lessoniana dengan padat penebaran yang berbeda. Laporan Penelitian Balai Penelitian Perikanan Pantai, 12 hal. (belum dipublikasikan)

Hamzah, M.S. dan N. Manik. 1991. Pendugaan pertumbuhan dan mortalitas sotong buluh, Sepioteuthis lessoniana Lesson di perairan kepulauan Kai Kecil, Maluku Tenggara. Dalam Perairan Maluku Tenggara. Balai Penelitian dan Pengem. bangan Sumberdaya Laut, Pusat Penelitian dan Pengembangan Oseanologi. Lembaga Ilmu Pengetahuan Indonesia. 9-15

Huet, M. 1971. Texbook of fish culture: Breeding and cultivation of fish. Fishing News book Ltd., London. $436 \mathrm{pp}$.

National Research Council (NRC). 1977. Requirement of warmwater fishes. National Academic Sciences, Washington D.C. $78 \mathrm{pp}$.

Ray, P.J. 1979. Aquaculture. Institute of Biology's. Studies in biology, No.106. Edward Arnold Publisher Ltd., London $59 \mathrm{pp}$.

Roper, C.F.E., M.J. Sweeney and C.E. Nauen. 1984. Species catalogue. Vol.3. Cephalopods of the World. An annotated and illustrated catalogue of species of interest to fisheries. FAO Fish. Synop., 125(3): 109-111.

Sujoko, B. 1988. Cumi-cumi (Cephalophoda dan Mollusca) sebagai salah satu bahan makanan dari laut. OCEANA XIII(3): 97-107.

Yamaguchi, M. 1991. Broadclub cutlefish, Sepia latimanus. p.228-298. In Shokita S., K. Kakazu, A. Tomori and T. Toma (eds.) Aquaculture in Tropical Area. Mindoro Shobo Co. Ltd., Japan. 360 pp. 